the structure and control of thin films, ultrasonic and electromagnetic flowmeters, applications of semiconductors, and the design of a specific microscope objective. These formed but a part of the seventyseven exhibits, covering many aspects of the Association's work. Of particular interest, as indicating the importance of giving as much freedom as possible to the individual scientist, was the demonstration of a chemical balance which used flexure pivots in place of knife-edges. This development had no place in the research programme, but although the investigation is still in its early stages, a promising degree of robustness and sensitivity has been achieved. Another exhibit of potential value was the moisture-sensitive ceramic element. This was demonstrated, measuring humidities in the $0-1$ per cent region to about 0.02 per cent. The instrumental applications of graticules, devices which started as seales and now form an essential part of certain automatic control processes, are becoming more numerous every day. The exhibits concerned with graticules covered the whole field of their manufacture and application. British thermometer manufacturers now have at their command a method of making permanent markings on many of their products. The process for doing this, developed by the Association, was the subject of another exhibit. Pneumatic gauging, as developed by the Mechanical Department, excited considerable interest.

The extent of the services provided by the Information Department came as a surprise to many visitors, particularly the range of technical inquiries handled by the scientific staff of the Department. Working models of flexure pivots, illustrating devices described in one of the Department's publications, aroused much interest.

The speaker on October 7, Dr. T. E. Allibone, took as his subject "Black and White Elephants at Aluermaston". In the course of his lecture he described many discoveries and inventions made in his own laboratories which were apparently of little use, but had afterwards turned out to have considerable value. On October 8, Sir John Cockcroft spoke about "Nuclear Instrumentation" and directed attention to the enormous field for instruments which was being created by the planned reactor programme. On October 9, Prof. Casimir, from Holland, gave his audience a peep into the future by discussing "Atoms as Units", describing how atomic properties could be used as standards of length, time, electric charge and magnetic induction. Dr. Ponte, of Paris, gave a more detailed account of a particular branch of instrumentation on October 10. His subject, "Quartz Oscillators and their Limitations", was illustrated by slides of modern time-measuring equipment. $\mathrm{He}$ showed that an accuracy of 1 part in $10^{8}$ was now feasible with small, robust equipment. On October 11, Prof. S. Tolansky demonstrated the power of phase-contrast microscopy by means of many photographs of the detail of crystal structure in metals, convincingly illustrating that for the detection and measurement of the contours of a surface the optical method is comparable with the electron microscope.

A noteworthy feature of the open days was the exhibition of members' products to which the Research Association had made some contribution. It was a kind gesture on the part of the members and one which is bound to have a good effect on the morale of the staff thus to acknowledge some of the benefits which have accrued as a result of the Association's work.

\section{CONTROL OF ADMINISTRATIVE TRIBUNALS}

$\mathrm{N}$ opening a debate in the House of Commons on October 31, in which the House took note of the report of the Franks Committee on Administrative Tribunals and Enquiries, Mr. R. A. Butler said that the Government is concerned to accept as many of the recommendations of the report as possible. Nevertheless, it wishes to obtain the views of members on certain of the findings and particularly in the light of the three guiding principles of openness, fairness and impartiality. The Government believes it would be possible to accept wholly or substantially the majority of the detailed recommendations, while striking a just balance between the rights of the citizen and the efficient discharge of the country's business. The Government proposes to set up a single Council on Tribunals which will be appointed jointly by the Lord Chancellor and by the Secretary of State for Scotland, with a special committeo or panel of the Council to deal with matters of special concern to Scotland. The Council would be consulted before establishing any new tribunal and the Government would refer to the Council various recommendations made by the Franks Committee.

It is also proposed that, in general, chairmen should be appointed by the Lord Chancellor in England and Wales, and by the Lord President of the Court of Session in Scotland, and the Government agrees that for the most part it is desirable that chairmen of tribunals should have legal qualifications. The opinion of the House of Commons is to be obtained regarding the proposal to entrust adjudicating functions of county agricultural executive committees to new independent tribunals, with appeal to the Land Tribunal or to the Scottish Land Court. In future, it is proposed to appoint inspectors only after consultation with the Lord Chancellor, and the Minister would be free to dismiss chairmen only with the Lord Chancellor's consent. Mr. Butler said that the Government is also prepared to arrange for publication of inspector's reports and promised that in future responsible Ministers would ensure that more is done to make the policies for which they are responsible more widely understood, that people are told where they can find the information which may help them, and that authorities will be required in future to see that their case is properly set out before an inquiry opens. The statement was generally welcomed, and in replying on the debate the Attorney-General stressed the advisory functions of the proposed Council.

\section{EFFECT OF RADIATION ON HUMAN HEREDITY}

A

STUDY group, set up by the World Health Organization in Geneva to consider the effect of radiation on human heredity, has presented its report to the United Nations Scientific Committee on Atomic Radiation; in shortened form, the report has been prepared as a special feature of the Chronicle of the World Health Organization (11, No. 8 ; August 1957).

Each member of the group was acutely aware of the existing gaps in knowledge and drew up an inventory of problems which will need to be investigated by geneticists, nationally or internationally. 